EESTI NSV TEADUSTE AKADEEMIA TOIMETISED. XVIII KÖIDE

KEEMIA * GEOLOOGIA, 1969, Nr. 2

ИЗВЕСТИЯ АКАДЕМИИ НАУК ЭСТОНСКОЙ ССР. ТОМ ХVII

ХИМИЯ * ГЕОЛОГИЯ. 1969, № 2

\title{
ON THE FORMATION AND DEVELOPMENT OF THE MAMMALIAN FAUNA OF THE EAST BALTIC IN THE HOLOCENE
}

Owing to the favourable natural conditions and old traditions of relevant studies, the Baltic may be considered a classical territory for the elucidation of the regularities in the development of nature in the Holocene. In the development of the live nature of the East Baltic in the Holocene, of particular interest is the problem of the remigration into the former glacial area and further development of the flora and fauna that had emigrated to the south during the Pleistocene (Paaver, 1961). This problem is closely connected with the complex study of the Holocene, and its solution requires, next to a study of the palaeozoological material, a wide utilization of palaeogeographical, geological and archaeological data.

The basic material for the study of the mammalian fauna of the East Baltic is represented by archaeological finds of sub-fossil bone remains (up to the present time, over 150 thousand bones and bone fragments have been studied, which were found in about 80 mesolithic, neolithic and metal age settlements). The results of the study of the available materials (besides the above-mentioned, they also include finds of sub-fossil bones discovered elsewhere, written sources and results of the researches into the recent mammalian fauna) have been published in the monograph "Formation of the Mammalian Fauna of the Baltic Countries and Variability of Mammals of the Holocene" (Paaver, 1965). In the present paper, on the basis of the materials and concepts of the above-mentioned work, a brief survey is given of the basic features and stages in the process of the development of the mammalian fauna in the East Baltic.

For an understanding of the post-glacial history of the mammalians of the formation of the range and abundance of the species, changes in the inter-areal distribution, differentiation and adaptation of the population, interrelation between Man and fauna, as well as other phenomena - it is of importance to approach the faunistic complex of the Holocene from a differentiated point of view, with a consideration of its dynamics in time and space. The present fauna has developed in the East Baltic after the retreat of the ice, i. e. during less than the recent 15 thousand years. In fact, the primary post-glacial immigration of the mammalian species into the East Baltic was mainly effected in the Late Glacial time and in the Early Holocene. Beginning with the second half of the Holocene, this process is no longer reflected in the dynamics of the mammalian fauna of the East Baltic. The phenomena of the recent migration of mammalians in the East Baltic are to be explained by the influence of Man, by the secular fluctuations of the climate and other ecological factors, and are 
no proof of the continuation of the primary post-glacial immigration. In biogeographical relevant literature, the recolonization of the glacial areas by animal species is considered to be on the whole a result of the remigration into the territory lost during the glacial periods. This remigration does not represent a migration in the neozoological sense of the word, i. e. it is not to be imagined as an active migration of populations or herds, or as a mass expansion in the areas after the retreat of the ice, but as a gradual dispersal of the animals owing to the extension of the limits of the range of distribution.

The process of the primary immigration and the further changes in the distribution and abundance of the species depended on the specific biological character of the species (in particular, on the vagility and on the type of the formation of the distribution area) as well as on the conditions of dispersal over the territory under observation. On the basis of the factors determining the immigration of the mammalian species as well as with a consideration of the changes in the direction, extension and of the rhythm of those changes within the limits of distribution, we may differentiate in the post-glacial dynamics of the East Baltic fauna interrelated processes depending on the shifts in the limits of the climatic and vegetational zones, secular fluctuations of the climate as well as on Man's activity. In the Holocene (i. e. in the recent 10 thousand years, beginning with Phase IX in the development of forests), from the viewpoint of the history of the mammalian fauna, we may define three considerable zonal shifts in the climate and landscape of the surroundings of the East Baltic (the influence of the late-glacial shifts upon the formation of the East Baltic mammalian fauna can be characterized but indirectly, owing to the scantity of the paleozoological material).

1. The replacement of tundra and forest tundra by forests due to the continuous amelioration of the climate at the end of the Late-Glacial time and at the beginning of the Early Holocene. As a result of this shift, a continuous colonization of the woodland fauna started in the East Baltic, accompanied by a regression of the tundra fauna from this area. In connection with that shift, in the abruptly changed climatic conditions of the Early Holocene, of particular interest is the fate of a number of large mammals that had become adapted to the conditions of the late-glacial tundra-like landscape.

The reindeer (Rangifer tarandus L.) is considered to be a typical lateglacial species of the mammalian fauna of North Europe. In the East Baltic (and even more frequently on the territory of the neighbouring Kaliningrad Region), some finds of reindeer bones have been made, dating from the Post-Glacial time. However, no reindeer remains could be found in the archaeological excavations of the Holocene settlements (including the mesolithic Kunda settlement dating from the 8 th-6th millenniums before the present era). This fact allows us to assume that the reindeer existed in the Baltic in the Holocene as a permanent dweller only at the beginning of this period. From the western regions of the East Baltic it disappeared already at the close of the Late-Glacial time (Degerbøl, 1964). The early disappearance of the tundra reindeer from Denmark and its neighbouring regions is explained by $M$. Degerbøl by the rapid rise of the average summer temperature at the close of the Younger Dryas, which circumstance proved unfavourable for that form. The morphological analysis of the reindeer antlers found in the East Baltic points to the possibility that when the tundra form (it is considered to be closely related to the subspecies $R$. $t$. tarandus L.; Degerbøl and Krog, 1959) retreated from the 


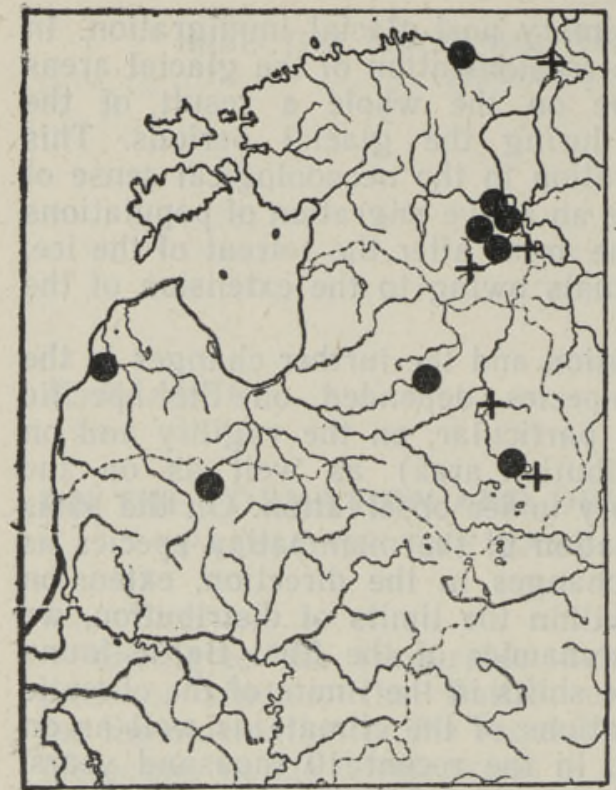

Fig. 1. Sites of subfossil bone finds of the wild horse (Equus caballus L.) (circles) and pond tortoise (Emys orbicularis L.) (crosses) in the East Baltic.

East Baltic, the northeastern and northern regions of the given territory were invaded by the forest form of $R$. $t$. fennicus Lönnberg. But the forest reindeer, too, seems to have disappeared from the East Baltic at quite an early date, at least before the beginning of the Boreal climatic period.

The finds of subfossil bones of the wild horse (Equus caballus L.) in Estonia and Latvia (including 280 bone remains found in the neolithic settlement of Kääpa, see Fig. $1)$, are evidence of the occurrence of this species in the Early and Middle Holocene on the eastern coast of the Baltic at up to $59^{\circ}$ of northern latitude. In the East Baltic, that species was rather rare; it seemingly lived here close to the northern border of its area. Its systematic relations to the other wild horse populations of Europe require further elucidation. The existence of the wild horse in the surroundings of the Baltic Sea in the Late Glacial time have been proved by bone finds in Denmark and West Germany (Degerbøl, 1964). Moreover, there are also discoveries of that species in Sweden and Denmark, dating from the Early Holocene (Lundholm, 1947; Degerbøl, 1943). However, it is not clear whether the form inhabiting the East Baltic in the Holocene was a direct successor of the "tundra horse" that had lived in those regions in the Late Glacial, or was a post-glacial immigrant from the south. Preliminarily, the wild horse of the East Baltic could be considered as belonging to the subspecies of E. c. ladogensis Gromova.

During the Younger Dryas the tundra-like landscape on the Baltic was populated by the large bison subspecies - Bison bonasus arbustotundrarum Degerbøl (judging by the finds in Holstinia, Denmark and Sweden). It is supposed that this bison subspecies had not been able to change the direction of its evolution at a rapid enough rate, and became extinct at the beginning of the Holocene.

Abundant Holocene finds in the East Baltic prove the existence, in that region, of the European bison subspecies $(B . \quad b$. bonasus L.) that had become adapted to forest conditions. In the 1st millennium of our era and in the 1 st half of the 2nd millennium the woodland bison was widely hunted as big game in Latvia and Lithuania. In Estonia, however, only single remains of the woodland bison were discovered dating from the first millennium of our era. The Late Holocene bison of the East Baltic was of a conspicuously big size, which shows that the rapid decrease in the body size of the East European bison was of a rather recent date, from the geological point of view, being due to unfavourable living conditions and not reflecting the natural evolutional development of the species.

2. The replacement of the Boreal pine and birch forests by broad-leaved deciduous forests at the 
beginning of the post-glacial warm period. The constant amelioration of the climate brought about the formation of the deciduous forest zone in East Europe at the beginning of the Middle Holocene (in connection with the shifting of the broad-leaved deciduous trees by up to $400 \mathrm{~km}$ northwards) at the beginning of the post-glacial warm period. This shift also brought along the expansion, to the East Baltic, of the so-called European faunistic complex of mammalian species (such as the wild cat, wild boar, roe deer, red deer, etc.) that had hitherto been distributed in the south of that region. The further history of each of those mammalian species in the East Baltic (according to their ecological adaptability and relationship with $\mathrm{Man}$ ) proceeded in a rather different manner; however, the changes in their abundance and distribution reveal several features in common.

Thus, for example, the red deer (Cervus elaphus L.) appeared in the East Baltic at the beginning of the post-glacial warm period. It was most wide-spread here in the Middle Holocene, but even then it was obviously not particularly numerous as compared to the other ungulates. After the deterioration of the climate in the Late Holocene, the red deer disappeared from the northern regions of the territory but it survived in the southern areas (in Lithuania) for a long time. By the time being, owing to reacclimatization, it has recolonized the major part of the territory under observation once again. The roe deer (Capreolus capreolus L.) too, immigrated in the East Baltic at the beginning of the post-glacial warm period. It was rather rare here during the whole of the Middle and partly also during the Late Holocene. It is only in the present millennium that the abundance of the roe deer has increased here. In the second half of the present millennium, during a period of cold winters, it retreated from the northern regions, reappearing again in the past century. In the Late Holocene the body size of the East Baltic roe deer increased considerably in comparison with what it was in the Middle Holocene.

Together with other species inhabiting deciduous forests, the wild cat (Felis silvestris Schreber)-appeared in the East Baltic at the beginning of the post-glacial warm period, as well. The maximum of its distribution and abundance coincides with the Middle Holocene. It probably retreated from the northern regions of the territory in the Late Holocene, after the deterioration of the climate, and from the southern regions only in the recent centuries (in connection with persecution by man and owing to the transformation of the landscape by human activity).

The history of the urus (Bos primigenius Bojanus) has proceeded in the West and East Baltic in a rather different way. This species appeared in Denmark as early as the close of the Pleistocene, and it was quite common there during the Boreal, but rare in the Atlantic period. It immigrated into the East Baltic in the Early Holocene, and during the entire postglacial warm period it was widely distributed and numerous there (Fig. 2). When the climate deteriorated in the Late Holocene, it disappeared from the northern regions, but stayed in Lithuania, in some places, until the middle of the present millennium. The East Baltic urus was of a large body size, in comparison with other populations, and its osteometric characters did not undergo any changes during the Holocene. The early colonization of the southwestern part of the territory by the urus could have been caused by the geographical position of the given area and by an early. formation of favourable conditions for that species, as compared with the northeastern regions of the East Baltic. The marked decrease in its abundance in Denmark already in the Atlantic period might have resulted from an early development of agriculture and farming in those parts. 

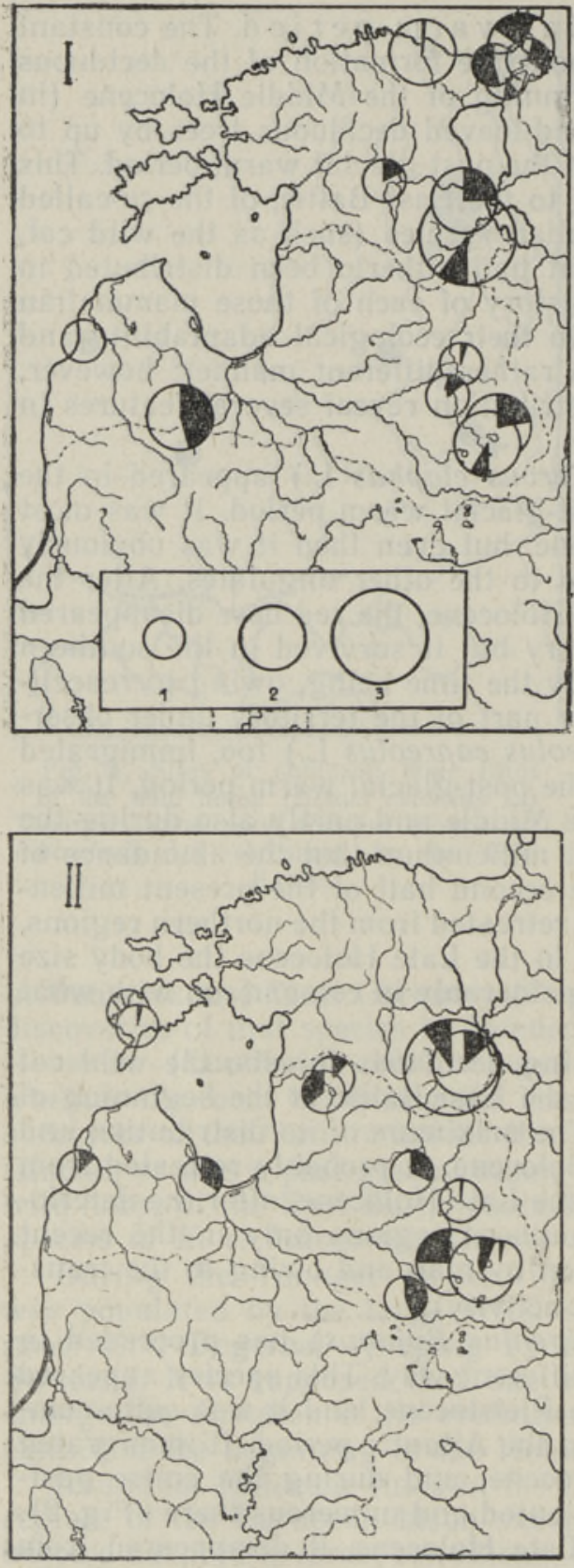

Fig. 2. The distribution of the subfossil bone remains of the urus (Bos primigenius Boj.) and their relative share in the osteological material discovered at archaeological excavations.

Dating of the sites: $\mathrm{I}-7 \mathrm{th}-3 \mathrm{rd}$ millennium before our era; II -2 nd millennium b. o. e. The black sector designates the percentage of the bones of the urus in the total number of the bones of other artiodactyls. The size of the circle shows the number of bones of artiodactyls: 1 - up to $500 ; 2-501-5,000 ; 3-5,001$ and more.
3. The decrease in the significance of the broadleaved deciduous forest and the increase in the significance of the coniferous (fir, later pine) forests at the end of the warm period and in the $\mathrm{L}$ ate Holocene. The expansion of fir forests in the East Baltic did not bring along any immigration of new mammalian species, but it contributed to a relative abundance of those woodland species that had appeared here in the Early Holocene and spread over a wide area, in connection with the decrease in the number of the deciduous forest species and a local disappearance of some species. A striking example illustrating the effect of the deterioration of the climate upon the vertebrate fauna was the extinction of the pond tortoise (Emys orbicularis L.) in Estonia and Latvia, where it had been widely distributed in the post-glacial warm period (see Fig. 1).

The dynamics of the mammalian fauna of the East Baltic which had been caused by zonal shifts were not merely a reflection of the changes in the climate and landscape of Eastern Europe, but they were simultaneously affected by local ecological conditions and biocenotical factors that modified, accelerated or retarded the processes effected.

Next to changes depending on the shifts in the climate and landscape zones, we may also state, in the dynamics of the Holocene mammalian fauna of the East Baltic, some changes in the abundance of the species as well as oscillations in the limits of their areas, which had been called forth by secular climatic fluctuations. Those pulsations involved first and foremost those species who had "climatic" distribution limits; they proceeded at a more rapid pace than the changes caused by zonal shifts, and they did not result in a continuous trans- 
formation of the fauna. The changes that were brought about by the pulsation of the limits of distribution ranges could be followed in detail during the recent two or three centuries. During the period of rough winters, in the so-called "little ice age" (17th cent. - 1st half of the 18th cent.), several species of a southern distribution area (roe deer, wild boar, etc.) grew less numerous in the northern regions of the East Baltic and became extinct in those parts. In the second half of the 19th century, a period of a warmer and more marine climate, which was felt in the Arctic and in the temperate zone, brought about a new rise in the abundance of those species and their transgression.

Apart from the secular fluctuations of the climate and zonal shifts, the post-glacial history of the mammalian fauna of the East Baltic has also been considerably affected by human activity, which started already in the Early Holocene, and in Lithuania, where man is known to have settled in the Late Glacial time, at an even earlier date. However, the beginning of notable changes in the mammalian fauna resulting from human activity might be only dated with the 2nd millennium before our era, when the areas thereto settled by hunters and fishers were invaded, from the south, by tribes whose chief occupation was animal husbandry and, possibly, agriculture. The persecution of great carnivores and ungulates, competitors and enemies of domestic animals, caused a gradual decrease in the abundance of the former. The transformation of the landscape by man, in its turn, contributed to the increase in the number of more open-landscape species (for example the brown hare (Lepus europaeus Pall.), to a decrease in the abundance of the forest species, and to a localization of the large wild mammalian species, driving them to areas rich in forests and bogs. The rapid rise of the influence of the anthropistic factor in the history of the mammalian fauna of the East Baltic countries is a particularly typical feature in the Late Holocene.

An analysis and generalization of the subfossil osteological material enables us to proceed to the periodization of the history of the mammalian fauna of the East Baltic and to connect it with the palaeogeographical scheme of the Holocene of the East Baltic countries as well as with the stages of their cultural development. In the development of the Holocene mammalian fauna of the East Baltic countries we may differentiate three stages. The Early Holocene mammalian fauna. The typical forms are wide-spread (Euro-Siberian) forest species. The broad-leaved deciduous forest species of a southern distribution are either lacking or rare (in the second half of the stage). The Middle Holocene mam. $\mathrm{mal} \mathrm{i}$ a $\mathrm{n}$ f a u na. The common deciduous forest species are well represented over the whole area. In the second part of the stage, their relative abundance (as compared to Euro-Siberian forest species) decreases. The $\mathrm{L}$ ate $\mathrm{Hol}$ ocene $\mathrm{mammali}$ an f a n a. A typical feature are widespread forest species; in the southern regions, the broad-leaved deciduous forest species are also common. Human activity results in considerable changes in the distribution and abundance of the mammalians. 


\section{REFERENCES}

Dege r b 1 M. 1943. Om Dyrelivet i Aamosen ved undløse paa Sjaelland i Stenalderen. Nord. Fortidsminder, 3, H. 3.

Degerbol M. 1964. Some remarks on late- and post-glacial vertebrate fauna and its ecological relations in Northern Europe. J. Anim. Ecol., 33 (Supp.)

D e g e r b ol M., Krog H. 1959. The reindeer (Rangifer tarandus L.) in Denmark. D. Kgl. Dan. Vid. Selskab. Bid. Skrift., 10, Nr. 4.

Lundholm B. 1947. Abstammung und Domestikation des Hauspferdes. Zool. Bidr. Uppsala, 27.

P a a ver K. 1961. Baltimaade subfossiilse imetajatefauna uurimisest seoses looduslike tingimuste muutumisega jääajajärgsel ajal. ENSV TA Geol. Inst. uurimused, VII.

П а а в е р К. Л. 1965. Формирование териофауны и изменчивость млекопитающих Прибалтики в голоцене. Тарту.

Academy of Sciences of the Estonian SSR,

Received

Institute of Zoology and Botany

Dec. 12,1968

\section{K. PAAVER}

\section{BALTIMAADE TERIOFAUNA KUJUNEMISEST JA DONAAMIKAST HOLOTSEENIS}

Paleograafiliste tingimuste foonil käsitletakse imetajaliikide esmast levimist Baltimaile ning muutusi nende levikus ja arvukuses sel alal. Siinse teriofauna formeerumisel olid suure tähtsusega klimaatilis-maastikulised nihked hilisjääaja, vara- ja keskholotseeni lōpul. Kliima sekulaarsed kõikumised olid nendega vōrreldes allutatud tähtsusega. Inimese tegevuse järjest suurenevat mõju teriofaunale võib täheldada alates keskholotseeni teisest poolest.

Liigilise koostise ning liikide komplekside arvukussuhete alusel vōib Baltimaade teriofauna ajaloos eraldada kolme pōhietappi, mis vastavad vara-, kesk- ja hilisholotseenile.

\section{K. ПААВЕP}

\section{О ФОРМИРОВАНИИ И ДИНАМИКЕ ТЕРИОФАУНЫ ПРИБАЛТИКИ В ГОЛОЦЕНЕ}

В статье дается краткий обзор истории териофауны млекопитающих Восточной Прибалтики в послеледниковое время. Рассматривается первичное заселение этой обласіи видами млекопитающих, а также последующие изменения в их распространении и численности. В динамике териофауны Прибалтики большое значение имели ландшафтноклнматические сдвиги в конце позднеледниковья, а также в конце раннего и среднего голсцена. Вековые колебания климата играли более подчиненную роль. Влияние человека приобретало все возрастающее значение со второй половины среднего голоцена.

В голоценовой истории териофауны Прибалтики можно выделить три основных этапа, соответствующих раннему, среднему и позднему голоцену и различающихся по видовому составу и относительной численности видов зверей и их комплексов. 